\title{
THE RENAL EXCRETION OF INULIN AT LOW PLASMA CONCEN- TRATIONS OF THIS COMPOUND, AND ITS RELATIONSHIP TO THE GLOMERULAR FILTRATION RATE IN NORMAL, NEPHRITIC AND HYPERTENSIVE INDIVIDUALS ${ }^{1}$

\author{
By BENJAMIN F. MILLER, ALF S. ALVING AND JACK RUBIN
}

(From the Department of Medicine, University of Chicago, Chicago)

(Received for publication August 21, 1939)

Precise measurements of many of the physiological characteristics of the kidney depend on the principle that the clearance of any freely filtrable compound which is excreted only by the glomeruli is identical with the filtration rate. Rehberg, the first investigator to apply this principle to the human kidney, suggested the use of exogenous creatinine as a measure of the filtration rate (1). Later it was demonstrated that exogenous creatinine is excreted by the tubules as well as the glomeruli of the human kidney (2). Many other compounds have been suggested for the measurement of glomerular filtration rate in man, but of these only inulin has achieved wide acceptance. The evidence supporting the inulin clearance as a measure of filtration has been reviewed extensively by Smith (3), and needs no detailed repetition. The evidence so far presented is not entirely conclusive and consists chiefly, if one omits the rather questionable evidence based on consideration of the diffusion characteristics of inulin and its behavior in species far removed from the human, of three types of observations: (a) when tubular function is depressed by phlorizin, or when the tubular cells are "saturated" with glucose, ascorbic acid, etc., the clearances of a number of compounds approach the value of the inulin clearance $(3)$; $(b)$ the inulin clearance remains constant when the plasma concentration of inulin is varied over a wide range (4); and $(c)$ in a certain number of cases the specifically determined, endogenous creatinine clearance is equal to the inulin clearance (5).

The evidence supporting the inulin clearance would be much strengthened if several compounds of different molecular configuration could be shown to possess the same excretion characteristics as inulin. Such correspondence has been

1 Aided by a grant from the Douglas Smith Foundation for Medical Research of the University of Chicago. demonstrated in the dog for inulin, creatinine and ferrocyanide, but the same relationship does not hold for the human kidney. ${ }^{2}$

Shannon and Smith (4) have rightfully stressed the importance of the fact that the inulin clearance in normal and phlorizinized man is independent of the plasma concentration. In their experiments they varied the plasma concentration from 50 to $400 \mathrm{mgm}$. per $100 \mathrm{cc}$. and observed complete independence of the clearance values in this range. However, we feel that these excellent observations need amplification in two respects: one, the observations do not include patients suffering from nephritis or hypertension, and the other, that in the range of relatively high plasma concentration which they studied, these authors could have observed the effects of only rather considerable amounts of tubular excretion or reabsorption. That is, upon consideration of minimal variations in clearances from period to period and also of the minimal errors involved in the numerous analytical manipulations, it appears that secretion or reabsorption of $5 \mathrm{mgm}$. per minute of inulin could not have been noted by these authors, and possibly quantities somewhat larger might have escaped detection. It can be shown by a simple calculation, as developed later in the section on DIscussion, that such quantities of secreted or reabsorbed inulin could be detected readily by clearance studies at plasma levels below $20 \mathrm{mgm}$. per cent. Previous analytical methods for the determination of inulin were inadequate for study of inulin clearances at such low plasma concentrations. Recently, a sufficiently sensitive and precise method has been introduced by Alving, Rubin, and Miller (6). With this method we have been able, in the pres-

2 Recent preliminary studies by Smith (10) suggest that sorbitol and mannitol are excreted like inulin entirely by glomerular filtration. 
ent paper, to make the needed comparison of the inulin clearances at high and very low plasma levels in normal, nephritic and hypertensive individuals.

\section{Calculation of the clearances}

Inulin clearances were obtained by dividing the urinary excretion of inulin per minute by the concentration in the serum at the mid-point of the period. In those experiments in which constant infusions were given the blood was drawn at the mid-point of the period. In others, in which a single dose of inulin was injected, a number of blood samples were analyzed and their concentrations plotted on semi-logarithm paper. The midpoint concentrations were obtained from the graph and it was sufficiently accurate for our purposes to take this mid-point concentration as the average for the period.

Urea clearances were calculated by the usual formula of UV/B whenever the urine volume was greater than $2 \mathrm{cc}$. per minute, as it was in almost all the periods of every experiment but one. In the one experiment where the urine volumes were below the "augmentation limit" the urea clearances were calculated as $U \sqrt{V} / B$.

\section{Analytical methods}

Fresh urine specimens and blood serum were employed for all the analyses.

Inulin. Analyses of inulin were performed on cadmium filtrates by the colorimetric method of Alving, Rubin, and Miller, with the single modification of the substitution of a Number 635 Evelyn filter in place of the 660 filter recommended originally. The acid-alcohol, diphenylamine reagent was made fresh each day. Glucose in the serum and urine was removed by fermentation with yeast; fermentation is necessary when the urine inulin concentration is low, even in the presence of a negative Benedict's test for glucose.

To obtain as precise inulin clearance values as possible, the urines were diluted to contain nearly the same concentration of inulin as the corresponding serum filtrates.

Urea. The urea in the serum filtrates was determined by the hypobromite method of Van Slyke and Kugel (7) and the urea in urine by the urease method of Van Slyke (8).

\section{Plan of experiments}

Two types of experiments were performed. In one, continuous infusions of inulin were given to maintain constant plasma levels, and in the other type a single injection of inulin was made and the clearances obtained on a falling curve of plasma concentration. For both types of experiments certain technical details were the same, as follows: The subjects were kept in bed for 12 hours before the experiment. Breakfast consisted of toast, butter, and one-half glass of milk; $200 \mathrm{cc}$. of water were given every half or 1 hour for 3 hours before the first clearance period and also during the experiment.
Urine specimens were collected by catheterization, followed by three washings of the bladder with $20 \mathrm{cc}$. portions of physiological saline. The washings were added to the urine obtained by catheterization. Blood samples were obtained by venipuncture. In almost every experiment an active diuresis was obtained, and except for one experiment the urine volumes were considerably above 2 cc. per minute.

In the experiments with constant inulin plasma levels, a priming dose of inulin was given and this was followed immediately by the continuous injection of a dilute solution of inulin in physiological saline. The quantities were calculated to give in the first plateau a constant level of approximately $5 \mathrm{mgm}$. per $100 \mathrm{cc}$. of plasma. The sustaining solutions were given at the rate of $2 \mathrm{cc}$. per minute by means of a special pump designed by Dr. H. R. Jacobs. Thirty minutes were allowed for equilibrium, then two or three clearance periods of 20 to 30 minutes' duration were obtained. Another dose was then given to raise the plasma concentration to the desired level, and the sustaining solution replaced with a more concentrated one. Again after the equilibrium period several more clearance periods were obtained.

In the other type of experiment, 10 grams of inulin in 100 cc. of physiological saline were administered intravenously. Blood samples were drawn at 45 minutes; 1 hour, 15 minutes; 1 hour, 45 minutes; 2 hours, 15 minutes; and 3 hours after the initial injection. Urine collections were begun 30 minutes after completion of the inulin injection, and were so timed that the above blood samples fell at the mid-points of the clearance periods.

\section{RESULTS}

Table I presents a summary of experiments on 6 normal individuals. In the first 3 experiments the inulin clearances were obtained at plasma levels maintained by constant intravenous injection, and in the other 3 , after a single intravenous injection of inulin. It is apparent that the inulin clearance at very low plasma levels corresponds closely to the values obtained at relatively high concentrations. In the first 3 experiments the average clearance at the lower plasma level is 12 per cent to 17 per cent lower than the average at the higher concentration. These differences are small when contrasted with the 900 to 1400 per cent increase of plasma concentration in these experiments. It is significant that in each of the first 3 experiments, at least one period in each lower plasma plateau had as low a urea/inulin clearance ratio as observed at the higher plasma level. This indicates that there is no real tendency for the inulin clearance to drop to a lower value with the decrease in plasma concentration. 
TABLE I

Clearances at high and low plasma concentrations of inulin in normal individuals

\begin{tabular}{|c|c|c|c|}
\hline \multirow{2}{*}{ Subject } & \multicolumn{2}{|c|}{ Inulin } & \multirow{2}{*}{$\begin{array}{c}\text { Ratio } \\
\text { urea/inulin } \\
\text { clearance }\end{array}$} \\
\hline & $\begin{array}{c}\text { Plasma } \\
\text { concentration }\end{array}$ & Clearance & \\
\hline $\begin{array}{l}\text { D. K. } \\
\text { Male } \\
23 \text { years }\end{array}$ & $\begin{array}{c}\text { mgm. per } 100 c c . \\
4.53 \\
4.55 \\
\\
56.1 \\
51.9 \\
49.6\end{array}$ & $\begin{array}{c}c c . \text { per min. } \\
\text { per } 1.7 s \text { sq. } m . \\
101 \\
120 \\
120 \\
116 \\
140\end{array}$ & $\begin{array}{l}0.60 \\
0.55 \\
0.56 \\
0.54 \\
0.53\end{array}$ \\
\hline $\begin{array}{l}\text { M. B. } \\
\text { Male } \\
21 \text { years }\end{array}$ & $\begin{array}{c}10.9 \\
9.89 \\
\\
96.4 \\
94.5\end{array}$ & $\begin{array}{l}105 \\
123 \\
\\
131 \\
125\end{array}$ & $\begin{array}{l}0.65 \\
0.54 \\
\\
0.48 \\
0.52\end{array}$ \\
\hline $\begin{array}{l}\text { B. E. } \\
\text { Male } \\
22 \text { years }\end{array}$ & $\begin{array}{r}3.3 \\
3.6 \\
\\
50.9 \\
45.7\end{array}$ & $\begin{array}{l}121 \\
121 \\
\\
150 \\
134\end{array}$ & $\begin{array}{l}0.50 \\
0.43 \\
\\
0.50 \\
0.48\end{array}$ \\
\hline $\begin{array}{l}\text { A. W. } \\
\text { Male } \\
31 \text { years }\end{array}$ & $\begin{array}{r}6.6 \\
10.5 \\
14.3 \\
21.5 \\
35.0\end{array}$ & $\begin{array}{l}113 \\
111 \\
119 \\
128 \\
130\end{array}$ & \\
\hline $\begin{array}{l}\text { L. B. } \\
\text { Female } \\
36 \text { years }\end{array}$ & $\begin{array}{c}7.07 \\
10.6 \\
14.3 \\
20.8 \\
34.7\end{array}$ & $\begin{array}{r}105 \\
109 \\
103 \\
89 \\
91\end{array}$ & \\
\hline $\begin{array}{l}\text { L. A. } \\
\text { Male } \\
44 \text { years }\end{array}$ & $\begin{array}{l}10.3 \\
14.6 \\
18.3 \\
25.4 \\
37.3\end{array}$ & $\begin{array}{l}93 \\
76 \\
91 \\
74 \\
86\end{array}$ & \\
\hline
\end{tabular}

If such a tendency did exist one would anticipate a consistent rise in the urea/inulin clearance ratio.

In the other 3 experiments performed after injection of a single dose of inulin, the results demonstrate the same tendency for the inulin clearance to retain at low plasma levels the same absolute value as at the higher concentrations. In 2 of the 3 experiments (L. B. and L. A.) the clearances are slightly higher at the low levels than at the higher plasma concentrations. This was due most likely to changes in the filtration rate during these periods, rather than to a specific effect of the low plasma concentration on the clearances. Since urea clearances were not obtained, these experiments are somewhat less satisfactory than the previous ones in which the urea/inulin ratio gives a relatively satisfactory index of any changes in the filtration rate that might have occurred from period to period. However, these 3 experiments demonstrate clearly that the inulin clearance at plasma levels of 5 to $10 \mathrm{mgm}$. per $100 \mathrm{cc}$. shows no consistent deviation from the clearances obtained at levels four to five times higher.

In Table II a summary is presented of the results obtained on 6 patients suffering from various types of nephritis. The results are essentially the same as those obtained with the normal indi-

TABLE II

Clearances at high and low plasma concentration of inulin in individuals with various types of nephritis

\begin{tabular}{|c|c|c|c|c|}
\hline \multirow{2}{*}{ Subject } & \multirow{2}{*}{ Diagnosis } & \multicolumn{2}{|c|}{ Inulin } & \multirow{2}{*}{$\begin{array}{c}\text { Ratio } \\
\text { urea/inulin } \\
\text { clearance }\end{array}$} \\
\hline & & $\begin{array}{l}\text { Plasma } \\
\text { concen- } \\
\text { tration }\end{array}$ & Clearance & \\
\hline $\begin{array}{l}\text { V. S. } \\
\text { Female } \\
23 \text { years }\end{array}$ & "Nephrosis" & $\begin{array}{c}\text { mgm. per } \\
100 \text { cc. } \\
4.81 \\
4.70 \\
70.9 \\
64.8\end{array}$ & $\begin{array}{c}c c . \text { per } \\
\text { min. per } \\
1.73 \text { sq. } m . \\
86.1 \\
86.8 \\
\\
110 \\
97.2\end{array}$ & $\begin{array}{l}0.63 \\
0.58 \\
\\
0.59 \\
0.45\end{array}$ \\
\hline $\begin{array}{l}\text { E. S. } \\
\text { Male } \\
25 \text { years }\end{array}$ & $\begin{array}{l}\text { Chronic } \\
\text { glomerulo- } \\
\text { nephritis }\end{array}$ & $\begin{array}{r}4.1 \\
4.4 \\
\\
10.0 \\
11.4 \\
71.8 \\
70.2\end{array}$ & $\begin{array}{l}60.0 \\
55.0 \\
\\
64.0 \\
59.0 \\
\\
68.0 \\
65.0\end{array}$ & $\begin{array}{l}0.77 \\
0.76 \\
\\
0.57 \\
0.61 \\
\\
0.58 \\
0.65\end{array}$ \\
\hline $\begin{array}{l}\text { A. T. } \\
\text { Male } \\
21 \text { years }\end{array}$ & $\begin{array}{l}\text { Chronic } \\
\text { glomerulo- } \\
\text { nephritis }\end{array}$ & $\begin{array}{c}8.03 \\
7.83 \\
6.98 \\
\\
85.2 \\
83.6 \\
82.5\end{array}$ & $\begin{array}{r}22.1 \\
16.5 \\
14.1 \\
\\
13.5 \\
16.3 \\
9.3\end{array}$ & $\begin{array}{l}0.41 \\
0.47 \\
0.46 \\
\\
0.33 \\
0.35 \\
0.37\end{array}$ \\
\hline $\begin{array}{l}\text { M. C. } \\
\text { Female } \\
37 \text { years }\end{array}$ & $\begin{array}{l}\text { Chronic } \\
\text { glomerulo- } \\
\text { nephritis }\end{array}$ & $\begin{array}{r}7.7 \\
7.4 \\
7.4 \\
\\
67.1 \\
61.5 \\
61.2\end{array}$ & $\begin{array}{l}22.1 \\
20.8 \\
19.0 \\
\\
23.5 \\
20.3 \\
22.2\end{array}$ & $\begin{array}{l}0.80 \\
0.88 \\
0.82 \\
\\
0.79 \\
0.79 \\
0.77\end{array}$ \\
\hline $\begin{array}{l}\text { M. H. } \\
\text { Female } \\
39 \text { years }\end{array}$ & "Nephrosis" & $\begin{array}{r}6.9 \\
10.0 \\
13.0 \\
19.1 \\
27.7\end{array}$ & $\begin{array}{r}93.3 \\
107.4 \\
122.6 \\
85.8 \\
110.8\end{array}$ & \\
\hline $\begin{array}{l}\text { B. E. } \\
\text { Male } \\
20 \text { years }\end{array}$ & $\begin{array}{l}\text { Subacute } \\
\text { glomerulo- } \\
\text { nephritis }\end{array}$ & $\begin{array}{r}8.7 \\
13.3 \\
18.4 \\
25.5 \\
36.0\end{array}$ & $\begin{array}{r}92.8 \\
88.5 \\
89.3 \\
103.0 \\
80.7\end{array}$ & \\
\hline
\end{tabular}


viduals and show the independence of the inulin clearance from plasma concentration. The cases studied show considerable variety in the clinical picture of Bright's disease. Two cases (A. T. and $M . C$.) were typical advanced cases of chronic glomerulonephritis with marked loss of renal function. One patient (B. E.) had the disease for 4 months without much impairment of renal function; the remaining patient with glomerulonephritis (E. S.) had the disease for 4 years, and at the time of the experiment showed about 50 per cent of normal kidney function. In the other 2 patients (V. S. and M. H.) the diagnostic criteria corresponded to those of so-called genuine lipoid nephrosis; however, as generally turns out to be the case, these patients will probably be shown eventually to have been in the nephrotic stage of chronic glomerulonephritis.

The results of experiments on 3 patients suffering from severe essential hypertension are given in Table III. The inulin clearances in 2 of the patients (M. F. and B. H.) have the same values at the low plasma level as at the higher ones. In the remaining patient (L. M.) the absolute values of the clearances obtained at 4.2 to $4.5 \mathrm{mgm}$. per cent are lower than those at 38 to $50 \mathrm{mgm}$. per

TABLE III

Clearances at high and low plasma concentration of inulin in individuals with essential hypertension

\begin{tabular}{|c|c|c|c|}
\hline \multirow{2}{*}{ Subject } & \multicolumn{2}{|c|}{ Inulin } & \multirow{2}{*}{$\begin{array}{c}\text { Ratio } \\
\text { urea/inulin } \\
\text { clearance }\end{array}$} \\
\hline & $\begin{array}{c}\text { Plasma } \\
\text { concentration }\end{array}$ & Clearance & \\
\hline $\begin{array}{l}\text { M. F. } \\
\text { Male } \\
46 \text { years }\end{array}$ & $\begin{array}{c}\text { mgm. per } 100 \mathrm{cc} . \\
6.1 \\
5.6 \\
65.9\end{array}$ & $\begin{array}{c}\text { cc. per min. } \\
\text { per 1.78 sq. } m . \\
71.4 \\
76.4 \\
69.0\end{array}$ & $\begin{array}{l}0.59 \\
0.52 \\
0.54\end{array}$ \\
\hline $\begin{array}{l}\text { B. } H . \\
\text { Male } \\
25 \text { years }\end{array}$ & $\begin{array}{r}5.7 \\
5.7 \\
13.9 \\
12.4 \\
36.9 \\
32.7\end{array}$ & $\begin{array}{l}122.0 \\
108 \\
102 \\
107 \\
103 \\
118\end{array}$ & \\
\hline $\begin{array}{l}\text { L. M. } \\
\text { Female } \\
38 \text { years }\end{array}$ & $\begin{array}{r}4.5 \\
4.5 \\
4.2 \\
49.7 \\
43.9 \\
38.0\end{array}$ & $\begin{array}{r}95.2 \\
94.4 \\
68.8 \\
117.8 \\
113.6 \\
99.1\end{array}$ & $\begin{array}{l}0.64 \\
0.58 \\
0.80 \\
\\
0.47 \\
0.53 \\
0.45\end{array}$ \\
\hline
\end{tabular}

cent. These differences appear to be due to a specific effect of the plasma level of inulin since there was an elevation of the urea/inulin ratio at the lower level. In the third period of the low plasma plateau the effect is very marked, and the inulin clearance in this period is about $50 \mathrm{cc}$. below the next period obtained at a much higher plasma concentration. Even so, as brought out later in the discussion, this unusually low clearance, which represents an exceptional case in our experiments, would indicate the reabsorption of only $2 \mathrm{mgm}$. of inulin per minute.

\section{DISCUSSION}

The experiments described in this paper were designed to detect possible tubular excretion or reabsorption of inulin by the kidney of normal human subjects and also in individuals suffering from nephritis and hypertension. It is axiomatic that the amount of an inert compound excreted entirely by glomerular filtration has within certain wide limits no maximum, and its excretion is directly proportional to plasma concentration. However, since tubular excretion and reabsorption are in most cases dependent on specific activities of the tubule cells, these processes tend to have well-defined maximal rates. Thus filtration may easily mask the effect of tubular activity if proportionality between clearance and plasma concentration is studied at high plasma values. This phenomenon, and the rationale of our experiments, can be illustrated best by the calculations shown in Table IV. As pointed out in the introduction, it is reasonable to assume that the tubular excretion or reabsorption of $5 \mathrm{mgm}$. per minute of inulin could not have been detected by

\section{TABLE IV}

Deviations of the inulin clearance from the true filtration rate that would result from tubular excretion or reabsorption of a small quantity of inulin (a filtration rate of $100 \mathrm{cc}$. per minute is arbitrarily chosen)

\begin{tabular}{|c|c|c|}
\hline \multirow[b]{2}{*}{ Plasma inulin } & \multicolumn{2}{|c|}{ Inulin clearance } \\
\hline & $\begin{array}{l}\text { Assuming tubular } \\
\text { excretion of } 5 \text { mgm. } \\
\text { inulin per minute }\end{array}$ & $\begin{array}{l}\text { Assuming tubular } \\
\text { reabsorption of } 5 \mathrm{mgm} \text {. } \\
\text { inulin per minute }\end{array}$ \\
\hline \multicolumn{3}{|l|}{$\begin{array}{l}\text { mgm. per } \\
100 \text { cc. }\end{array}$} \\
\hline $\begin{array}{r}100 \\
20 \\
5\end{array}$ & $\begin{array}{l}105 \\
125 \\
200\end{array}$ & $\begin{array}{r}95 \\
75 \\
0\end{array}$ \\
\hline
\end{tabular}


previous experiments which were conducted at relatively high plasma concentration. If, for example, one assumes a true filtration rate of 100 cc. per minute at a plasma value of $100 \mathrm{mgm}$. per cent (a value used very frequently in experiments with inulin) then the assumed amount of tubular excretion or reabsorption would have caused the clearance to change to $105 \mathrm{cc}$. or $95 \mathrm{cc}$. respectively. It is doubtful whether the analytical methods employed would have detected the change, or if they had, whether any particular significance could be attached to a $5 \mathrm{cc}$. per minute variation in clearance from period to period.

However, if the clearances had been determined at $20 \mathrm{mgm}$. per cent plasma concentration, then the $5 \mathrm{mgm}$. tubular excretion or reabsorption of inulin would have caused the clearance to change to $125 \mathrm{cc}$. and $75 \mathrm{cc}$. respectively. These deviations from the true filtration level of $100 \mathrm{cc}$. could be detected. At a plasma level of $5 \mathrm{mgm}$. per cent, the $5 \mathrm{mgm}$. tubular excretion or reabsorption would give clearances of 200 or 0 respectively!

The results of our experiments show that at plasma levels in the range of $5 \mathrm{mgm}$. per cent the inulin clearance has essentially the same value as at the high ranges of plasma concentration. This appears to rule out definitely the possibility of any appreciable amount of active tubular excretion or reabsorption of a fixed quantity of inulin. In a few experiments, it is true, the clearance values were slightly lower at the low plateau than at the high one. For the normal individuals, the experiment on B. E. shows the greatest difference between the clearance at low and high plasma values. Assuming that the difference between the clearances of 121 and 150 was caused by tubular reabsorption of inulin, then the amount reabsorbed would be $29 \times 0.036=1 \mathrm{mgm}$. per minute. It is problematical whether even such a slight quantity of reabsorption occurred in this experiment because the urea/inulin ratios were relatively constant throughout the entire experiment. Thus it appears from the experiments on normal individuals that there is no tubular excretion of inulin and very little, if any, reabsorption of inulin by the normal kidney. Similarly, it can be said from the experiments on 6 nephritic individuals, that there is no greater tendency to tubu- lar excretion or reabsorption in the nephritic than in the normal kidney.

In 2 of the individuals with essential hypertension there was no evidence of tubular excretion or reabsorption of inulin. In the third case (L. M.) the last clearance obtained at the low plasma concentration was exceptionally low, $49 \mathrm{cc}$. below the first clearance at the high plasma plateau. This low clearance could have been caused by the reabsorption of $49 \times 0.042=2.1 \mathrm{mgm}$. of inulin per minute. The analyses for this period were rechecked and found to be correct. Also, the urea/inulin clearance ratio rose suddenly in this period to the unusually high value of 0.80 . The high ratio could conceivably be caused by the reabsorption of an unusually small percentage of the filtered urea, but this seems improbable because the urea clearance agreed with the values for preceding and succeeding periods. Hence, this period probably represents an exceptional example in which the kidney tubules reabsorbed a slight, but definite, quantity of inulin. It is probably fortuitous that this exceptional result was found in a patient with hypertension rather than in a normal or nephritic individual.

It is possible to raise an obvious objection to the type of reasoning employed in these experiments. We have assumed that, if tubular excretion or reabsorption of inulin does occur, the maximum amount of inulin capable of crossing the tubules would be a relatively fixed quantity per minute. One may argue that the tubular reabsorption or excretion of inulin would be proportional to the concentration in the plasma; that is, a constant percentage of the inulin brought to the kidneys would be transported across the tubule cells. Such an hypothesis cannot be excluded though no data support it. However, the extensive evidence now available on the function of the tubules indicates that they can excrete or reabsorb relatively fixed maximal quantities of a number of compounds (9). Thus the basic assumption which is made in this paper regarding the excretion of inulin is entirely compatible with the known facts.

It may be asked whether it is worthwhile to ascertain if the inulin clearance is a precise measure of the filtration rate. Would not the clearance be as satisfactory for physiological and clinical measurements if it were within 5 per cent of 
the true value? In most cases the absolutely precise value may not be necessary, but it becomes highly important whenever one investigates tubular activity at high plasma concentrations of a given compound. For example, in ascertaining the maximum quantity of exogenous creatinine excreted by the tubule cells (2), it may be necessary to subtract a filtration value of 120 from a creatinine clearance of 135 to obtain the "tubular clearance." It is apparent that even a few per cent uncertainty in the true filtration rate would introduce large percentage errors in the estimation of the tubular clearance.

The demonstration that the inulin clearance at low plasma concentration has the same value as at the high levels previously employed leads to certain practical applications. In the first place it permits one to do experiments after the injection of relatively small quantities of inulin. This reduces the dangers from reaction to the pyrogenic material which is found sometimes in the most carefully purified inulin. Also, reduction of the quantity of inulin represents a considerable saving of money when many experiments are performed. Another important advantage is the opportunity afforded to follow the inulin clearance for very long periods of time after a single intravenous injection of inulin. And finally, one may determine glomerular filtration rate very simply in the normal or diseased human kidney. The details of a simplified clinical procedure for the measurement of glomerular filtration rate will be described elsewhere.

\section{SUMMARY}

Inulin clearances have been determined at very low plasma levels by the sensitive, colorimetric method devised by Alving, Rubin and Miller for this purpose. As shown by calculation, small quantities of tubular excretion or reabsorption of inulin would cause the inulin clearance at low plasma levels to deviate markedly from the values obtained at high plasma concentrations. Our results demonstrate that the inulin clearance in the range of $5 \mathrm{mgm}$. per $100 \mathrm{cc}$. of plasma closely approximates the clearance obtained at much higher plasma concentrations. The results indicate that in most cases there is no tubular excretion or reabsorption of inulin. In an occasional clearance period there was a possible reabsorption of 1 or $2 \mathrm{mgm}$. of inulin per minute, amounts which may be considered negligible for most purposes.

Studies have been made on normal individuals and patients with severe essential hypertension and various types of nephritis. Our results support the evidence, accumulated chiefly by $\mathrm{H}$. W. Smith, J. A. Shannon, and their collaborators, for the inulin clearance as a precise measure of the glomerular filtration rate in the normal human kidney, and strengthen the evidence for the diseased kidney.

The authors are indebted to the Pfanstiehl Company for generous gifts of inulin.

\section{BIBLIOGRAPHY}

1. Rehberg, P. B., Studies on kidney function. I. The rate of filtration and reabsorption in the human kidney. Biochem. J., 1926, 20, 447.

2. Shannon, J. A., The renal excretion of creatinine in man. J. Clin. Invest., 1935, 14, 403.

3. Smith, H. W., The Physiology of the Kidney. The Oxford University Press, New York, 1937.

4. Shannon, J. A., and Smith, H. W., The excretion of inulin, xylose and urea by normal and phlorizinized man. J. Clin. Invest., 1935, 14, 393.

5. Miller, B. F., and Winkler, A. W., The renal excretion of endogenous creatinine in man; comparison with exogenous creatinine and inulin. J. Clin. Invest., 1938, 17, 31.

6. Alving, A. S., Rubin, J., and Miller, B. F., A direct colorimetric method for the determination of inulin in blood and urine. J. Biol. Chem., 1939, 127, 609.

7. Van Slyke, D. D., and Kugel, V., Improvements in manometric micro-kjeldahl and blood urea methods. J. Biol. Chem., 1933, 102, 489.

8. Van Slyke, D. D., Determination of urea by gasometric measurement of the carbon dioxide formed by the action of urease. J. Biol. Chem., 1927, 73, 695.

9. Shannon, J. A., Renal tubular excretion. Physiol. Rev., 1939, 19, 63.

10. Smith, H. W., Porter Lectures. University Extension Division, University of Kansas, Lawrence, Kansas, 1939, Series IX. 